\title{
Degeneration rate of goat primordial follicles maintained in TCM 199 or PBS at different temperatures and incubation times
}

\author{
Taxa de degeneração de folículos primordiais caprinos conservados em TCM 199 ou PBS em diferentes \\ temperaturas e tempos de incubação
}

\author{
José Roberto Viana Silva ${ }^{2 *}$ Alline Ferreira Brasil ${ }^{2}$ Regiane Rodrigues dos Santos ${ }^{2}$ Sônia \\ Helena Furtado Costa ${ }^{2}$ Ana Paula Ribeiro Rodrigues ${ }^{2}$ Marcos Antônio Leal Ferreira ${ }^{2}$ \\ Vanessa Porto Machado ${ }^{2}$ José Ricardo de Figueiredo ${ }^{1}$
}

\section{ABSTRACT}

\begin{abstract}
The present work has investigated the degeneration rate of goat primordial follicles in situ after preservation in PBS or TCM 199 at different temperatures and incubation times. For each animal the ovarian pair was divided into 19 fragments. One ovarian fragment was taken randomly and immediately fixed (control). The other 18 ovarian fragments were randomly distributed in tubes containing PBS or TCM 199 and stored at $4^{\circ}, 20^{\circ}$ or $39^{\circ} \mathrm{C}$ for 4,12 or $24 \mathrm{~h}$. The storage of ovarian fragments in PBS or TCM 199 at $20^{\circ} \mathrm{C}$ for $12 \mathrm{~h}$ and $24 \mathrm{~h}$ or at $39^{\circ} \mathrm{C}$, in all incubation times tested, increased significantly the percentage of degenerated primordial follicles $(P<0.05)$. In contrast, for both media tested the degeneration rate of primordial follicles preserved at $4{ }^{\circ} \mathrm{C}$ for up to $24 \mathrm{~h}$ and at $20^{\circ} \mathrm{C}$ for $4 \mathrm{~h}$ was similar to control values $(P>0.05)$. In conclusion, this study shows that PBS was as efficient as TCM 199 in the preservation of goat primordial follicles in situ, being the best results observed at $4^{\circ} \mathrm{C}$.

Key words: primordial follicles, degeneration, goat, preservation.
\end{abstract}

\section{RESUMO}

O presente trabalho investigou a taxa de degeneração de folículos primordiais caprinos in situ após conservação em PBS ou TCM 199, em diferentes temperaturas e tempos de incubação. Para cada animal, o par ovariano foi dividido em 19 fragmentos. Um fragmento foi escolhido aleatoriamente e imediatamente fixado (controle). Os 18 fragmentos ovarianos restantes foram aleatoriamente distribuidos em tubos contendo PBS ou TCM 199 e conservados a 4, 20 or $39^{\circ} \mathrm{C}$ por 4,12 or $24 \mathrm{~h}$. A conservação de fragmentos ovarianos em PBS ou TCM 199 a $20^{\circ} \mathrm{C}$ por 12 e
$24 \mathrm{~h}$ ou a $39^{\circ} \mathrm{C}$, em todos os tempos de incubação testados, aumentou significativamente a percentagem de foliculos primordiais degenerados $(P<0,05)$. Ao contrário, em ambos os meios testados, a taxa de degeneração de folículos primordiais conservados $a 4^{\circ} \mathrm{C}$ em todos os tempos testados e a $20^{\circ} \mathrm{C}$ por $4 \mathrm{~h}$ foi similar ao controle $(P>0,05)$. Em conclusão, este estudo mostrou que o PBS foi tão eficiente quanto o TCM 199 na conservação de foliculos primordiais caprinos in situ, sendo os melhores resultados observados na temperatura de $4^{\circ} \mathrm{C}$.

Palavras-chave: folículos primordiais, degeneração, cabra, conservação.

\section{INTRODUCTION}

Primordial follicles constitute $95 \%$ of the thousands of follicles present in the mammal ovaries. Although most of primordial follicles undergo atresia during growth and maturation in vivo, these follicles provide a valuable source for studies on in vitro development of oocytes and eventual in vitro production of embryos (CARROL et al.,1990). The success of in vitro oocyte growth depends of the quality of their follicle. However, the ovarian donor of primordial follicles for in vitro studies is commonly encountered far away from the reproduction laboratories. In this respect, the preservation of ovaries during transportation to the laboratories becomes very important. In attempt to optimize in vitro preservation

${ }^{1}$ Professor Adjunto, Universidade Federal do Ceará (UECE).

${ }^{2}$ Estudante de Pós-graduação, PPGCV - UECE.

*Autor para correspondência: Universidade Estadual do Ceará, Faculdade de Veterinária, Avenida Paranjana, 1700, Campus do Itaperi, 60740-000, Fortaleza-CE, Brasil. E-mail: roberto_viana@yahoo.com 
conditions of ovaries, saline solution (CARVALHO et al., 2001), Braun-Collins (ANDRADE et al., 2001), coconut water solution (SILVA et al., 2000) and TCM 199 (FERREIRA et al., 2001) have been tested. However, these studies indicate only the overall incidence of follicular degeneration after preservation and considered all classes of preantral follicles (primordial, primary and secondary follicles together).

The PBS is commonly used as a preservation medium for embryos (NIEMANN, 1991) and cumulus oocyte complex (JEWGENOW et al.,1998). TCM 199 is another medium that has been successfully used in the preservation of bovine ovaries (FIGUEIREDO et al.,1993) and cumulus oocyte complexes (TWAGIRAMUNGU et al.,1998), during transportation. However, there are currently no studies investigating the degeneration rate of goat primordial follicles in situ after preservation in PBS or TCM 199.

The aim of this study was to evaluate the degeneration rate of goat primordial follicles after preservation in PBS or TCM 199 at different temperatures and incubation times.

\section{MATERIAL AND METHODS}

Ovaries $(\mathrm{n}=10)$ from 5 adult mixed breed goats were collected at a local slaughterhouse. The ovaries were stripped of surrounding fat tissue and ligaments and washed in $70 \%$ alcohol for approximately 10 seconds and then twice in $0.9 \%$ saline solution.

In the slaughterhouse, the ovarian pair from the same animal was divided into 19 fragments. One fragment was taken randomly and immediately fixed for histological examination (Control - Treatment 1 Time 0 ). The other 18 fragments were randomly distributed in tubes containing $2 \mathrm{~mL}$ of Hepes TCM $199+1.50 \mathrm{mM}$ Hepes (Cultilab-Brazil) or PBS (Cultilab-Brazil), at $4^{\circ}, 20^{\circ}$ or $39^{\circ} \mathrm{C}$ and stored for 4 , 12 or $24 \mathrm{~h}$ (Treatments 2 to 19). The temperatures were maintained using termosflasks filled with water at $4^{\circ}$, $20^{\circ}$ or $39^{\circ} \mathrm{C}$, and monitored through incubation time in each treatment, performed in five replication.

The control ovarian fragment was individually fixed in Carnoy for $24 \mathrm{~h}$ and dehydrated in a graded serie of ethanol, clarified with xylol and embbeded in parafin wax. The tissue was sectioned serially at a thickness of $7 \mu \mathrm{m}$, and every $5^{\text {th }}$ section was stained with periodic acid schiff (PAS) and hematoxylin. Each section was deparaffinated with xylol, rehydrated in graded alcohol, and examined by light microscopy (Leica) with $400 x$ magnification.
The primordial follicles present one layer of flattened or flattened-cuboidal granulosa cells around the oocyte (HULSHOF et al., 1994). The basement membrane, presence or absence of pycnotic bodies and integrity of the oocyte and granulosa cells were evaluated. Based on these parameters, primordial follicles were classified as morphologically normal follicles (Figure 1), degenerated type 1 follicles (only the oocyte was degenerated; Figure 1) and degenerated type 2 follicles (degenerated oocyte and granulosa cells; Figure 1). These three classifications were assigned on a basis of atresia observed in the control and/or combined with changes that occurred as a result of storage.

The effect of media, temperatures and preservation periods on the percentage of degenerated primordial follicles was analyzed using a Chi-square test. Values were considered statistically significant when $\mathrm{P}<0.05$.

\section{RESULTS}

Approximately 100 primordial follicles were analyzed per treatment. In the treatments tested, including the control, morphologically normal primordial follicles present a spherical oocyte, with uniform cytoplasm and well organized granulosa cells, without pycnotic nucleus (Figure 1). The degenerated

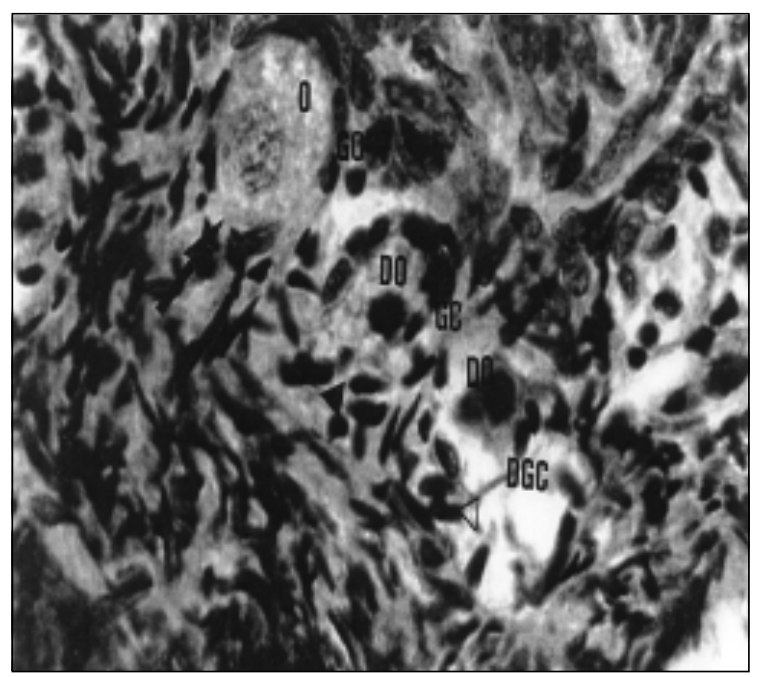

Figure 1 - Histological section of goat ovarian fragment after staining with PAS-hematoxylin, showing a normal primordial follicles (arrow), Type 1 degenerated primordial follicles (black arrowhead) and a Type 2 degenerated primordial follicles (white arrowhead). O: oocyte, GC: granulosa cells, DO: degenerated oocyte and DGC: degenerated granulosa cells (1000x). 
Type 1 follicles sometimes had a retracted oocyte, with a pycnotic nucleus and strongly stained cytoplasm (Figure 1). The oocyte and granulosa cells degeneration was found in Type 2 degenerated follicles. The follicles with this kind of degeneration showed pycnosis at the oocyte level, and also disorganized granulosa cells detached, from basement membrane (Figure 1).

Figure 2 shows the percentage of degenerated primordial follicles stored in TCM 199 or in PBS. Compared to the control, it was observed that the percentage of degenerated primordial follicles maintained in both solutions at $4^{\circ} \mathrm{C}$ for up to $24 \mathrm{~h}$ and at $20^{\circ} \mathrm{C}$ for $4 \mathrm{~h}$ was similar to control $(\mathrm{P}>0.05)$. However, after preservation in both solutions at $20^{\circ} \mathrm{C}$ for $12 \mathrm{~h}$ and $24 \mathrm{~h}$ or at $39^{\circ} \mathrm{C}$ in all incubation times tested, the percentage of degenerated primordial follicles increased significantly when compared with control values $(\mathrm{P}<0.05)$. The increase of incubation time, from $4 \mathrm{~h}$ to $12 \mathrm{~h}$ and $24 \mathrm{~h}$ did not affect significantly the percentage of degenerated primordial follicles after preservation in PBS or TCM 199 at $4^{\circ} \mathrm{C}$. Similar results were obtained in primordial follicles stored in both solutions at $20^{\circ} \mathrm{C}$ and $39^{\circ} \mathrm{C}$, with the increase of incubation time from $12 \mathrm{~h}$ to $24 \mathrm{~h}$. In contrast, primordial follicles stored in both solutions at $20^{\circ} \mathrm{C}$ and $39^{\circ} \mathrm{C}$ presented a significant increase in the percentage of degenerated primordial follicles with the increase of incubation time from $4 \mathrm{~h}$ to $12 \mathrm{~h}$ and from $4 \mathrm{~h}$ to $24 \mathrm{~h}$.

With regard to the effect of temperature at the same incubation time, the results showed that in both solutions, in all incubation times tested, there was a progressive increase in the percentage of degenerated primordial follicles with the increase of temperature from $4^{\circ}$ to $20^{\circ}$ and $39^{\circ} \mathrm{C}(\mathrm{P}<0.05)$, except for the storage time of $4 \mathrm{~h}$, at which the temperature of $20^{\circ} \mathrm{C}$ did not increase the percentage of degenerated follicles when compared with storage at $4^{\circ} \mathrm{C}(\mathrm{P}>0.05)$. When PBS was compared with TCM 199 at the same temperature and incubation time, no significant difference in the percentage of degenerated primordial follicles after incubation at $4^{\circ} \mathrm{C}, 20^{\circ} \mathrm{C}$ and $39^{\circ} \mathrm{C}$ for all incubation times tested was observed ( $\mathrm{P}>0.05$; Figure 2$)$.

Figure 3 shows the distribution of degenerated Type 1 and Type 2 primordial follicles, in the control and after storage in TCM 199 (Figure

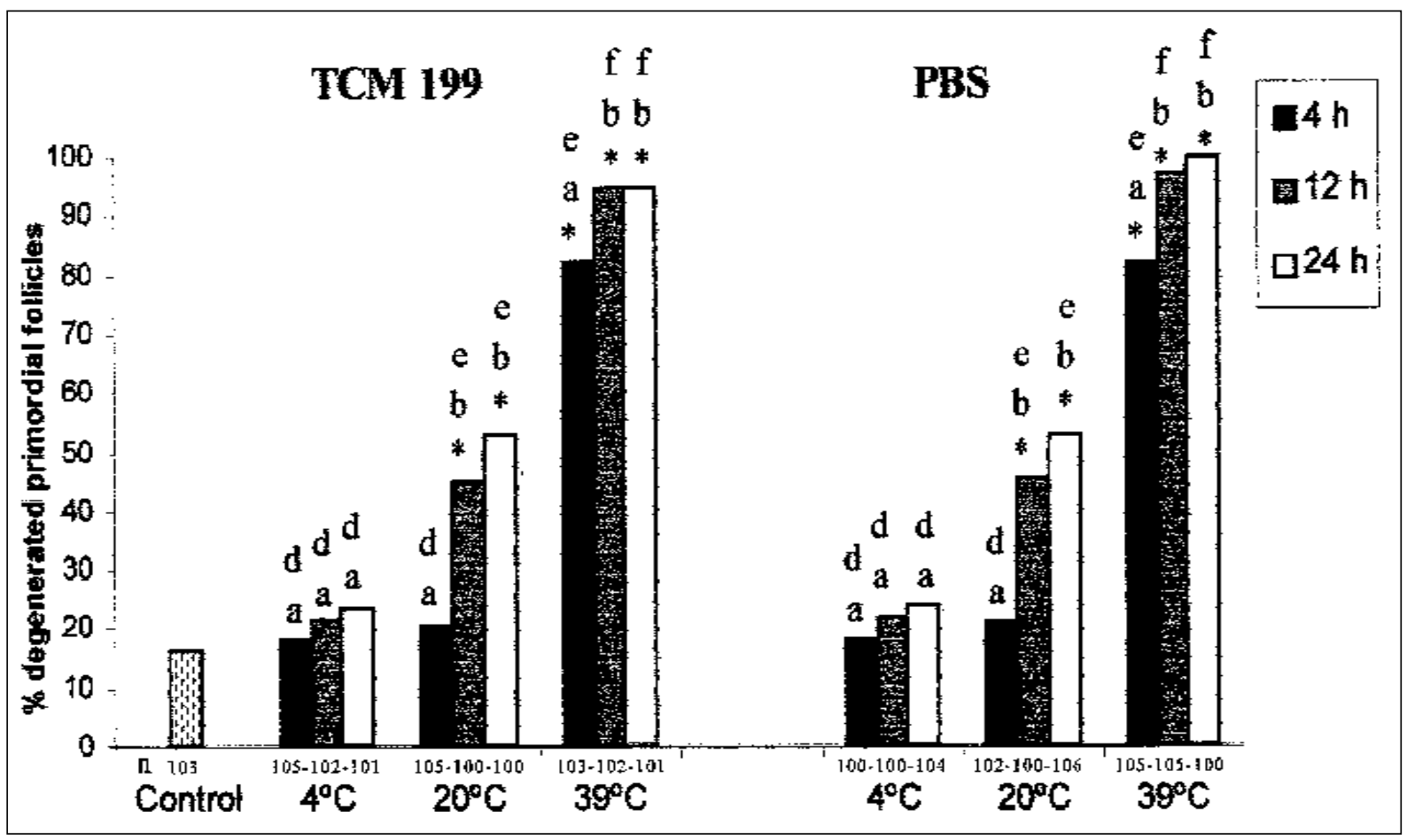

Figure 2 - Effect of temperature and incubation time on the percentage of goat degenerated primordial follicles preserved in TCM 199 and in PBS.

$\mathrm{n}$ : Number of primordial follicles analyzed per treatment, * Differs significantly from control $(\mathrm{P}<0.05)$. a,b - Different letters at the same incubation temperature show significant difference $(P<0.05)$. d,e,f - Different letters at the same incubation time show significant difference $(\mathrm{P}<0.05)$.

Ciência Rural, v. 33, n. 5, set-out, 2003. 


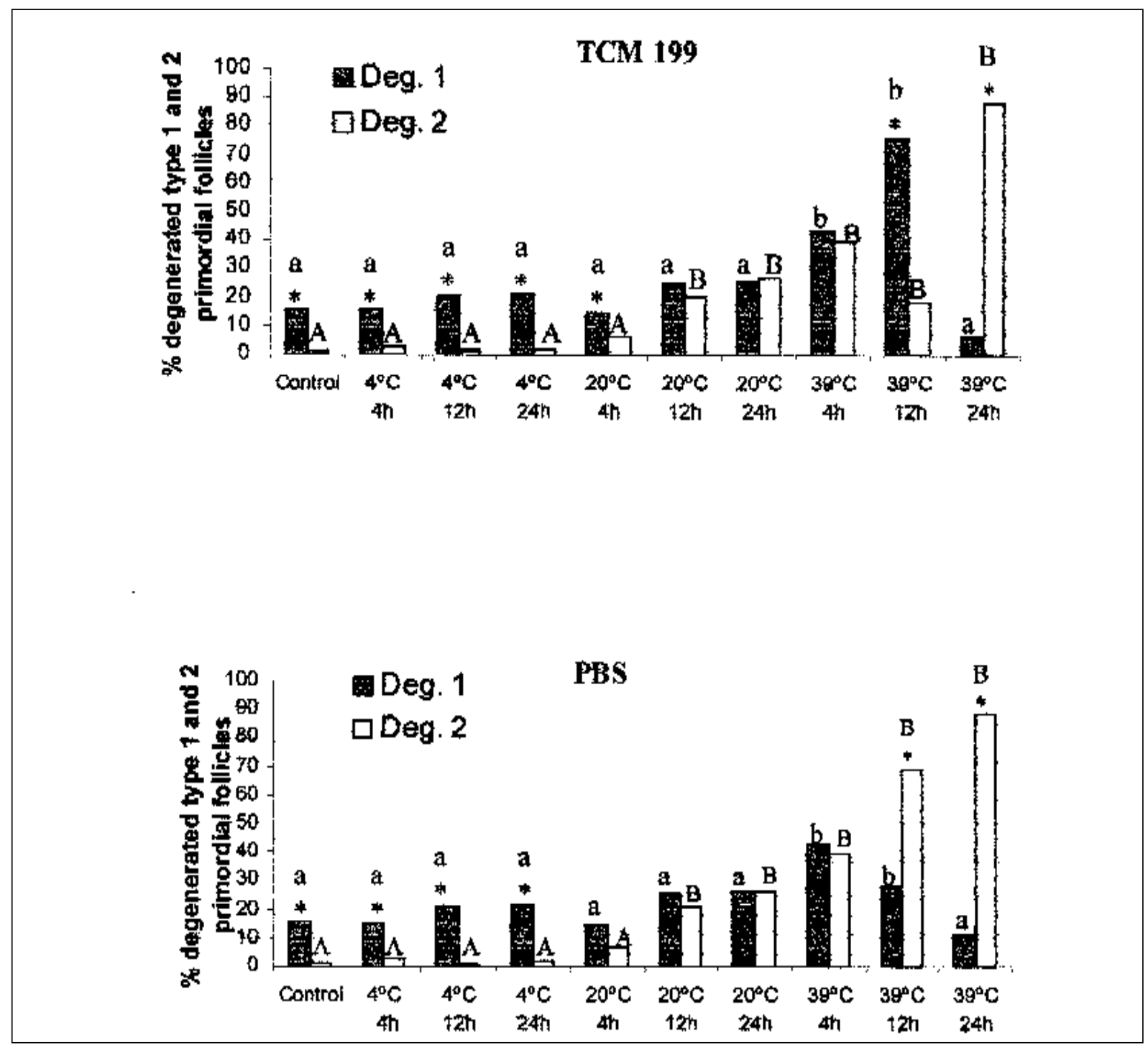

Figure 3 - Percentage distribution of the type 1 and 2 degenerated primordial follicles in goat ovaries, from the control and after storage in different treatments, in TCM 199 (A) and in PBS (B).

* indicates significant difference between the degeneration types in each treatment.

$\mathrm{a}, \mathrm{b}$ - different letters show significant differences in the percentage of degenerated type 1 follicles (Deg 1) found among different treatments and in the control $(\mathrm{P}<0.05)$.

$\mathrm{A}, \mathrm{B}$ - different letters show significant differences in the percentage of degenerated type 2 follicles (Deg 2) found among different treatments and in the control $(\mathrm{P}<0.05)$.

3A), and in PBS (Figure 3B). There was no significant difference in the percentage of degenerated Type 1 primordial follicles between the control and after storage in both solution at $4^{\circ} \mathrm{C}$ and $20^{\circ} \mathrm{C}$ at all incubation times tested, and at $39^{\circ} \mathrm{C}$ for $24 \mathrm{~h}$. However, in ovarian fragments stored in both solutions at $39^{\circ} \mathrm{C}$ for $4 \mathrm{~h}$ and $12 \mathrm{~h}$ a significant increase in the percentage of degenerated Type 1 follicles was observed when compared to control. On the other hand, a higher percentage of degenerated Type 2 follicles, compared to control, was observed in the fragments stored in both solutions at $20^{\circ} \mathrm{C}$ for $12 \mathrm{~h}$ and $24 \mathrm{~h}$ and at $39^{\circ} \mathrm{C}$ at all incubation times tested.

There was a predominance of degenerated type 1 follicles in the control and in the fragments stored at $4{ }^{\circ} \mathrm{C}$, in both solutions, at all incubation times $(\mathrm{P}<0.05)$. In contrast, it was observed a predominance of degenerated type 2 follicles in the fragments stored at $39^{\circ} \mathrm{C}$ for $12 \mathrm{~h}$ and $24 \mathrm{~h}$, in both solutions, except when the storage was performed 
in TCM 199 for $12 \mathrm{~h}$, where the percentage of degenerated type 1 was higher than degenerated type 2 (Figure 3).

\section{DISCUSSION}

This study evaluated specifically the sensitivity of primordial follicles to undergo degeneration after in vitro preservation and shows that the storage of ovarian fragments in PBS or TCM 199 at $20^{\circ}$ or $39^{\circ} \mathrm{C}$ increased the degeneration rate of goat primordial follicles. By contrast, the preservation of these follicles in both media at $4^{\circ} \mathrm{C}$ maintained the level of degeneration similar to that observed in vivo (control).

The storage of ovarian fragments in both solutions at $4^{\circ} \mathrm{C}$ for up $24 \mathrm{~h}$ and at $20^{\circ} \mathrm{C}$ for $4 \mathrm{~h}$ maintained the percentage of degenerated primordial follicles similar to that found in the ovary, immediately after animal death (control - time zero). Although the studies available did not evaluate the effect of media and temperature on the preservation of specifically primordial follicles, i.e. they considered all classes of preantral follicles together, the results from these studies demonstrated that the temperature of $4^{\circ} \mathrm{C}$ has been successfully used in the follicular preservation for $24 \mathrm{~h}$ in a solution poor in nutrients (SalineCARVALHO et al., 2001) or hyperosmotic (BraunCollins solution - SILVA et al., 2000) which shows that at $4^{\circ} \mathrm{C}$ the composition of the medium is not a limiting factor. In addition, WOOD et al. (1997) preserved successfully domestic cat ovarian follicles at $4^{\circ} \mathrm{C}$ for $48 \mathrm{~h}$. ROY \& TREACY (1993) observed that a lower metabolic rate at low temperatures may be beneficial in maintaining viable human preantral follicles in vitro after isolation. The hypothermia provoked by low temperatures $\left(4^{\circ} \mathrm{C}\right)$, that might have reduced cellular metabolism, consequently minimizing the metabolic need and increasing the resistance of follicles to the reduction of nutrients and oxygen during preservation in vitro.

This work shows that when the primordial follicles were stored in PBS or in TCM 199 at $20^{\circ} \mathrm{C}$ for $12 \mathrm{~h}$ and $24 \mathrm{~h}$ or $39^{\circ} \mathrm{C}$ at all incubation times, an increase in the percentage of degenerated primordial follicles was observed when compared to control. Similar results were observed with preservation of preantral follicles (without specific follicular type) at $20^{\circ} \mathrm{C}$ and $39^{\circ} \mathrm{C}$ for 12 and $24 \mathrm{~h}$ in saline (goat CARVALHO et al., 2001; sheep - ANDRADE et al.,2001), TCM 199 (goat - FERREIRA et al., 2001) as well as in Braun-Collins or coconut water solution (goat - SILVA et al., 2000) showing that even in a poor or rich nutrient media, a high degeneration rate were observed. The normal $\left(39^{\circ} \mathrm{C}\right)$ or subnormal $\left(20^{\circ} \mathrm{C}\right)$ metabolism associated with low oxygen tension in vitro could result in a higher rate of follicular degeneration found in the treatments where the ovarian fragments were stored at $20^{\circ} \mathrm{C}$ and $39^{\circ} \mathrm{C}$. JENNINGS et al. (1975) suggested that changes in the cellular membrane permeability induced by lack of oxygen, caused changes at a level of intracellular $\mathrm{Na}^{+}, \mathrm{K}^{+}$and $\mathrm{Cl}^{-}$, that associated with changes in the distribution of $\mathrm{Ca}^{+}$and increase of intracellular water, may lead to increased cellular volume and consequently cellular degeneration.

Overall, the increase in incubation temperature from $4^{\circ} \mathrm{C}$ to $20^{\circ} \mathrm{C}$ or $39^{\circ} \mathrm{C}$, as well as the increase in the incubation time from $4 \mathrm{~h}$ to $12 \mathrm{~h}$ after preservation at $20^{\circ} \mathrm{C}$ and from $4 \mathrm{~h}$ to $24 \mathrm{~h}$ at $39^{\circ} \mathrm{C}$, in both solutions, increased significantly the percentage of degenerated follicles. At $20^{\circ} \mathrm{C}$ or $39^{\circ} \mathrm{C}$ the increase of the incubation period could cause firstly the depletion of intracellular energetic sources and then the nutrients and oxygen available in the preservation media, indispensable for the maintenance of follicular viability. Although preantral follicles are able to survive for a short periods under hypoxia conditions (SMITZ et al., 1996) and glycolisis can sustain its viability during a limited period, the presence of oxygen is necessary to assure the normal follicular development (BOLAND et al., 1994). Oxygen deficiency can lead to degeneration and death when the cellular metabolism is within the normal limit $\left(39^{\circ} \mathrm{C}\right)$ or close to it $\left(20^{\circ} \mathrm{C}\right)$. On the other hand, in contrast to our results, when goat preantral follicles were preserved at $20^{\circ} \mathrm{C}$ for $4 \mathrm{~h}$ in hyperosmotic solution (Braun-Collins solution - SILVA et al., 2000) a great percentage of degeneration was observed, showing that at this condition the osmolarity of the medium may be an important factor.

In relation to degeneration type present in primordial follicles, the histological analysis of fresh ovarian fragments (control) and after preservation, in both solutions, at $4^{\circ} \mathrm{C}$ for up $24 \mathrm{~h}$ showed a significant predominance of Type 1 degeneration. The main alteration observed in these follicles was pycnosis in the oocyte nucleus. According to WOOD et al. (1997), the first index of degeneration in preantral follicles is oocyte degeneration, whereas the first indicator in antral follicles is usually related to the granulosa cells. Similar results using fresh ovaries were obtained studying preantral follicles of cow (ERICKSON, 1986), rat (HIRSHFIELD, 1988), and goat (LUCCI et al., 1999). WOOD et al. (1997) obtained similar results after preservation of cat preantral follicles in 
PBS for 48h. According DRIANCOURT \& THUEL (1998) the oocyte is the first cell within the follicle to be affected by atresia, and whether oocyte atresia is related to oocyte defects or to an improper dialogue between the oocyte and its surrounding granulosa cells remains unclear. In addition, we show in previous study that the oocyte of goat preantral follicles were more sensitive to degeneration than granulosa cells (SILVA et al., 2001). In contrast, in both solutions after preservation at $39^{\circ} \mathrm{C}$ for $12 \mathrm{~h}$ and $24 \mathrm{~h}$, there were significantly higher percentage of primordial follicles with degenerated oocyte and granulosa cells, i.e., Type 2 degeneration. Granulosa cells of the degenerated follicles were disorganized and enlarged in volume. Pycnotic nucleus and/or cytoplasm shrinkage were observed in the oocyte. According to CORTVRINDT et al. (1996), the oocyte retraction occurs due to the rupture of gap junctions that bind oocyte to the granulosa cells.

In conclusion, this study shows that PBS is as efficient as TCM 199 in the preservation of goat primordial follicles in situ. For both media, the storage of ovarian fragments at $20^{\circ} \mathrm{C}$ or $39^{\circ} \mathrm{C}$ increase significantly the degeneration rate of primordial follicles. The low degeneration rate of primordial follicles in situ after preservation at $4^{\circ} \mathrm{C}$ may be usefull in assuring good quality of follicles after transportation to specialized laboratories, which could be important to provide healthy oocytes for use in culture and/or cryopreservation, thus enhancing the efficiency of animal reproduction in the future.

\section{REFERENCES}

ANDRADE, E.R. et al. Short term maintenance of sheep preantral follicles in situ in $0.9 \%$ saline and Braun-Collins solution. Small Ruminant Research, Amsterdam, v.41, p.141-149, 2001.

BOLAND, M.I. et al. Characterization of follicular energy metabolism. Human Reproduction, Oxford, v.9, p.604-609, 1994.

CARROLL, J. et al. Extra-ovarian production of mature viable mouse oocytes from frozen primary follicles. Journal of Reproduction and Fertility, Cambridge, v.90, p.321-327, 1990.

CARVALHO, F.C. et al. Effect of Braun Collins and saline solutions at different temperatures and incubation times on the quality of goat preantral follicles preserved in situ. Animal Reproduction Science, Amsterdam, v.66, p.195-208, 2001.

CORTVRINDT, R.; SMITZ J.; VAN STEIRTEGHEM, A.C. A morphological and functional study of the effect of slow freezing followed by complete in vitro maturation of primary mouse ovarian follicles. Human Reproduction, Oxford, v.11, p.2648-2655, 1996.
DRIANCOURT, M.; THUEL, B. Control of oocyte growth and maturation by follicular cells and molecules present in follicular fluid. A review. Reproduction Nutrition and Development, Paris, v.38, p.345-362, 1998.

ERICKSON, G.F. An analysis of follicle development and ovum maturation. Seminars in reproductive endocrinology, v.4, p.233-254, 1986.

FERREIRA, M.A.L. et al. Effects of storage time and temperature on atresia of goat preantral follicles held in M 199 with or without indole-3-acetic acid supplementation. Theriogenology, New York, v.55, n.8, p.1607-1617, 2001.

FIGUEIREDO, J. R. et al. Development of a combined new mechanical and enzymatic method for isolation of intact preantral follicles from fetal, calf and adult bovine ovaries. Theriogenology, New York, v.40, p.789-799, 1993.

HIRSHFIELD, A.N. Size frequency analysis of atresia in cycling rats. Biolology of Reproduction, Madison, v.38, p.1181-1188, 1988.

HULSHOF, S.C.J. et al. Isolation and characterization of preantral follicles from fetal bovine ovaries. Veterinary Quarterly, London, v.16, p.78-80, 1994.

JENNINGS, R.B.; GANOTE, C.E.; REIMER, K.R. Ischemic tissue injury. American Journal of Pathology, New York, v.81, p.179-197, 1975.

JEWGENOW, K. et al. Viability of small preantral ovarian follicles from domestic cats after cryoprotectant exposure and cryopreservation. Journal of Reproduction and Fertility, Cambridge, v.112, p.39-47,1998.

LUCCI, C.M. et al. Study of preantral follicle population in situ and after mechanical isolation from caprine ovaries at different reproductive stages. Animal Reproduction Science, Amsterdam, v.56, p.223-236, 1999.

NIEMANN, H. Cryopreservation of ova and embryos from livestock: current status and research needs. Theriogenology, New York, v.35, p.109-124, 1991.

ROY, S.K.; TREACY, B.J. Isolation and long-term culture of human preantral follicles. Fertility and Sterility, New York, v.59, p.783-790, 1993.

SILVA, J.R.V. et al. Effect of coconut water and BraunCollins solutions at different temperatures and incubation times on the morphology of goat preantral follicles preserved in situ. Theriogenology, New York, v.54, p.809-822, 2000.

SILVA, J.R.V. et al. Morphological and ultrastructural changes occurring during degeneration of goat preantral follicles preserved in vitro. Animal Reproduction Science, Amsterdam, v.66, p.209-223, 2001.

SMITZ, J.; CORTVRINDT, R.; STEIRTEGHEBM, C. VAN. Normal oxygen atmosphere is essential for the solitary long-term culture of early preantral mouse follicles. Molecular Reproduction and Development, New York, v.45, p.466-475, 1996. 
TWAGIRAMUNGU, H. et al. Media and time of oocyte transport influence their developmental competence for in vitro production of bovine embryos. Theriogenology, New York, 1998 , p.299.
WOOD, T.C.; MONTALI, R.J.; WILDT, D.E. Follicle-oocyte atresia and temporal taphonomy in cold-stored domestic cat ovaries. Molecular Reproduction and Development, New York, v.46, p.190-200, 1997.

Ciência Rural, v. 33, n. 5, set-out, 2003. 